\title{
MANAJEMEN USAHATANI KOMODITAS JAMUR TIRAM BERKELANJUTAN DI DESA TULUNGREJO KECAMATAN BUMIAJI KOTA BATU
}

\author{
MANAGEMENT OF SUSTAINABLE OYSTER MUSHROOM COMMODITIES \\ IN TULUNGREJO VILLAGE, BUMIAJI DISTRICT, BATU CITY
}

\section{A. NURUL HARIYANTO, MUKHAMMAD ABDAN FADHOLY, ANDREANA FATHUR ROZI}

Fakultas Pertanian, Universitas Jember

Email : ahmadnurul855@gmail.com, abdan.kupang@gmail.com, andreagri607@gmail.com

\begin{abstract}
ABSTRAK
Komoditas jamur tiram banyak dibudidayakan di Kota Batu. Desa Tulungrejo Kecamatan Bumiaji cocok dijadikan sebagai daerah pengembangan jamur tiram, karena kondisi lingkungan yang mendukung. Metode penelitian yang digunakan yaitu dengan metode deskriptif kualitatif dengan menggunakan data primer dan data sekunder, kemudian dianalisis menggunakan metode analisis data Miles and Huberman. Hasil analisis menunjukkan bahwa manajemen usahatani komoditas jamur tiram di Desa Tulungrejo Kecamatan Bumiaji Kota Batu sudah berjalan dengan baik mulai dari tahap kegiatan pembibitan, sterilisasi, inokulasi, perawatan, dan pemanenan. Manajemen usahatani berkelanjutan pada komoditas jamur tiram di Desa Tulungrejo Kecamatan Bumiaji Kota Batu dilaksanakan berdasarkan masalah atau kendala yang dihadapi. Tujuan dari penelitian ini yaitu untuk menyelesaikan masalah dan kendala yang ada pada manajemen usahatani dalam menjalankan usahatani disektor hortikultura pada komoditas jamur tiram agar usaha yang dijalankan dapat berkelanjutan.
\end{abstract}

Kata Kunci: Jamur tiram, Manajemen, Usahatani

\section{ABSTRACT}

Oyster mushroom commodities are widelay cultivad ini Batu City. Tulungrejo Village, Bumiaji Subdistrict, is suitable as an oyster mushroom development area, because of the favorable environmental conditions. The research method used is descriptive qualitative method using primary data and secondary data, then analyzed using data analysis methods Miles and Huberman. The results of the analisis show that the on-farm management of oyster mushroom commodity in Tulungrejo Village, Bumiaji District, Batu City has been running well, starting form the stage of seeding activities, sterilization, inoculation, treatment, and harvesting. The concept of sustainable agribusiness on oyster mushroom commodities in Tulungrejo Village, Bumiaji District, Batu City is implemenof based on the problems or constraints faced. The purpose of this research is to solve the problems and contrains that exist in farm management in running farming in the horticultural sector of oyster mushroom commodity so that the business can be run sustainablay.

Kewords: Agribusiness, oyster mushroom, management

\section{PENDAHULUAN}

Pertanian merupakan suatu budidaya tanaman kedalam suatu lahan yang bertujuan untuk mencukupi kebutuhan manusia. Pertanian dapat diartikan dalam arti sempit dan dalam arti luas. Pertanian dalam arti sempit biasanya disebut dengan pertanian rakyat, sedangkan pertanian dalam arti luas merupakan pertanian yang meliputi pertanian dalam arti sempit, pertenakan, kehutanan, dan perikanan. Subsektor pertanian terdiri dari subsektor 
tanaman pangan, subsektor pertenakan, subsektor kehutanan, subsektor hortikultura dan subsektor perkebunan (Lailatusysyukriah, 2015).

Pembangunan pertanian merupakan suatu tindakan untuk mengubah suatu kondisi pertanian dari kondisi yang kurang menguntungkan menjadi kondisi yang lebih menguntungkan. Pembangunan pertanian berkelanjutan merupakan rancangan yang dikeluarkan untuk membuat strategi kegiatan yang memperhatikan faktor alam untuk dapat diolah lagi atau lingkungan tersebut dapat terawat. Pembangunan pertanian memegang peranan strategis dalam perekonomian. Kontribusinya dapat dirasakan secara nyata melalui pembentukan penyediaan bahan pangan, bahan baku industri, dan penyerapan tenaga kerja (Sjamsir, 2017).

Agribisnis merupakan suatu sistem bidang pertanian yang tidak semata-mata fokus pada kegiatan produksi atau usahatani saja, melainkan terdiri dari beberapa subsistem didalamnya, antara lain agroinput, usahatani, pengolahan atau agroindustri, dan pemasaran produk. Agribisnsis menjadi sebuag sistem yang dapat menambah nilai produksi pertanian untuk meningkatkan pendapatan dan produktivitas usahatani sekaligus dengan meningkatnya pengetahuan untuk perkembangan di bidang pertanian. Upaya dalam mencapai keberhasilan perlu dilakukan sebuah kolaborasi yang baik antar subsistem karena subsistem satu dengan yang lain saling berkaitan. Sehingga setiap subsitem harus dikerjakan dengan optimal (Israwati et al., 2018).

Menurut Firdaus (2017), usahatani jamur tiram harus menerapkan sistem manajemen yang baik, sehingga usahatani menjadi terarah dan dapat mencapai tujuan. Manajemen adalah suatu perpaduan antara ilmu dan seni dalam proses pelaksanaan suatu tujuan yang akan dicapai dalam kegiatan usaha tani sehingga dapat dengan mudah melakukan dan memantau kegiatan usahatani. Penerapan fungsi manajemen dalam sebuah usaha bertujuan untuk meminimalkan kerugian dalam menjalankan kegiatan produksi.

Menurut BPS Kota Batu (2020), Kota batu merupakan salah satu kota dijawa timur yang banyak membudidayakan komoditas hortikultura. Kota batu dapat memproduksi jamur tiram sebesar 932.97 Kw pada tahun 2017 dan pada tahun 2018 dapat menghasilkan 558.05 Kw. Kota Batu tidak hanya sebagai produsen apel di provinsi jawa timur, Kota Batu juga merupakan pengahasil komoditas hortikultura jamur. Kota Batu dipilih sebagai lokasi budidaya karena sifat 
geografis Kota Batu yang dingin dan cuaca yang cocok untuk pengembangan jamur tiram, karena Kota Batu berada pada ketinggian 700-1.700 mdpl. Hal tersebut yang mendasari pembudidaya jamur memilih Kota Batu sebagai salah satu kota Tabel 1.1 Data Produksi dan Luas Lahan Jamur di Kota Batu Tahun 2016-2018.

\begin{tabular}{cccc}
\hline No. & Tahun & $\begin{array}{c}\text { Produksi } \\
\text { (ton) }\end{array}$ & $\begin{array}{c}\text { Luas Lahan } \\
\text { (ha) }\end{array}$ \\
\hline 1 & 2016 & 808,04 & 13,22 \\
2 & 2017 & 932,97 & 12,29 \\
3 & 2018 & 558,05 & 10,27 \\
\hline Total & & $\mathbf{2 . 2 9 9 , 0 6}$ & $\mathbf{3 5 , 7 8}$ \\
\hline
\end{tabular}

Sumber: BPS Kota Batu, 2020

Berdasarkan table 1.1 dapat dilihat bahwa produksi jamur mengalami peningkatan pada tahun 2016 ke tahun 2017 sebesar 124,93 ton. Terjadi penurunan produksi pada tahun 2017 ke tahun 2018 sebesar 374, 92 ton. Hasil produksi tertinggi pada tahun 2017 sebesar 932,97 dengan jumlah produksi pada 3 tahun sebesar 2.229,06. Luas lahan budidaya jamur di Kota Batu mengalami penurunan setiap tahunnya mulai dari 13,22 ha pada tahun 2016 sampai 10,27 ha pada tahun 2018.

Tanaman jamur merupakan tanaman hortikultura yang permintaannya banyak dibutuhkan dipasaran. Kebutuhan konsumen akan jamur tiram belum bisa dipenuhi secara maksimal oleh produsen. Komoditas jamur menjadi peluang bisnis dan banyak dibudidayakan karena peluang budidaya jamur. Berikut data produktivitas komoditas hortikultura jamur beserta luas lahan produksi di Kota Batu pada tahun 2016-2018.

pasar dan perawatannya yang tidak begitu susah (Retnaningsih dan Bambang (2018). Menurut (Zulfarina et al. (2019), prospek jamur tiram yang mulai banyak dibudidayakan oleh para petani, karena jamur tiram cukup banyak digemari oleh masyarakat dan memiliki kandungan gizi yang tinggi, seperti kalori, protein, karbohidrat, lemak, vitamin dan sebagainya. Budidaya jamur tiram yang mudah dan tidak memerlukan lahan yang begitu luas dalam kegiatan produksinya membuat para petani mulai melakukan budidaya jamur tiram.

Jamur tiram memiliki karakteristik yang mudah rusak dan tidak dapat disimpan terlalu lama, sehingga diperlukan suatu perlakuan yang dapat meningkatkan daya simpan komuditas tersebut. Permasalah tersebut umum pada semua produk pertanian, komuditas jamur tiram merupakan salah satu tanaman hortikultura dengan hasil produktivitas yang cukup tinggi dibandingkan dengan tanaman hortikultura yang lainnya. Waktu panen yang serentak tidak diimbangi dengan 
kapasitas ruang penyimpan yang cukup membuat jamur tiram banyak mengalami pembusukan dan dibuang. Solusi dari permasalahan tersebut dalam mempertahankan kualitas jamur tiram diperlukan suatu sistem manajemen usahatani yang berkelanjutan (Wulandari et al., 2017).

\section{Usahatani yang ada di UKM} Agronusa Mushroom fokus pada komoditas Jamur tiram yang meliputi pembuatan bibit sampai dengan pemanenan. UKM Agronusa Mushroom dalam mengelola usahatani dan produksinya yaitu dilakukan secara mandiri. Produk yang dihasilkan berupa jamur tiram segar yang dijual secara mandiri pada agen-agen dipasar dan bermitra dengan CV. Arjuna Flora. Hal tersebut menunjukkan bahwa diperlukan sebuah pengetahuan terkait manajemen usahatani pada komoditas jamur tiram dalam usahataninya.

Rumusan Masalah

1. Bagaimana penerapan fungsi manajemen usahatani komoditas jamur tiram di UKM Agronusa Mushroom?

2. Bagaimana manajemen usahatani komoditas jamur tiram berkelanjutan di UKM Agronusa Mushroom?

Tujuan
1. Mengetahui manajemen usahatani komoditas jamur tiram di UKM Agronusa Mushroom

2. Mengetahui manajemen usahatani berkelanjutan yang dilakukan pada komoditas jamur tiram di UKM Agronusa Mushroom

\section{METODE PENELITIAN}

Metode yang digunakan yaitu (purposive method) atau pemilihan lokasi dilakukan secara sengaja dalam menentukan area penelitian dengan berbagai pertimbangan. Data yang digunakan dalam penelitian terdiri dari data primer dan data sekunder. Data primer ialah data yang diperoleh dari kegiatan wawancara, observasi, sedangkan data sekunder ialah data yang diperoleh dengan mengumpulkan data-data yang telah ada pada intansi terkait dan literatur-literatur yang relevan dengan masalah yang diteliti.

Penentuan responden pada penelitian menggunakan metode purposive sampling. Responden dalam penelitian ini yaitu pemilik dan karyawan usahatani jamur tiram pada UKM Agronusa Mushroom dengan melakukan wawancara mendalam menggunakan pertanyaanpertanyaan pada kuesioner yang telah disusun sebelumnya. Metode analisis data 
yang digunakan dalam penelitian ialah metode analisis data Miles and Huberman.

Definisi operasional yang digunakan dalam penelitian ini adalah sebagai berikut:

1) Jamur tiram merupakan komoditas hortikultura yang cukup banyak digemari oleh masyarakat dan memiliki kandungan gizi yang tinggi, seperti kalori, protein, karbohidrat, lemak, vitamin.

2) Usahatani merupakan kegiatan budidaya mulai dari pembibitan hingga pemanenan jamur tiram.

3) UKM Agronusa Mushroom menjadi lokasi budidaya jamur tiram di Desa Tulungrejo Kecamatan Bumiaji Kota Batu

4) Manajemen merupakan kegiatan yang berkaitan dengan perencanaan, pengorganisasian, pelaksanaan, evaluasi dan pengendalian

5) Kegiatan manajemen dalam usahatani UKM Agronusa Mushroom meliputi produksi, teknologi, sumber daya manusia, kemitraan atau kelembagaan dan pemasaran

6) Produksi merupakan kegiatan yang dikerjakan untuk menambah nilai guna suatu barang/jasa

7) Teknologi merupakan alat dan metode dalam membantu kegiatan usahatani jamur tiram di UKM Agronusa

Mushroom

8) Sumber daya manusia merupakan salah satu faktor yang penting dalam kegiatan usahatani jamur tiram di UKM Agronusa Mushroom

9) Kemitraan merupakan suatu kerjasama dalam kegiatan yang betujuan untuk membantu dalam semua kebutuhan pada kegiatan usahatani jamur tiram

10) Pemasaran merupakan kegiatan bisnis untuk memuaskan konsumen dengan menentukan harga, promosi, dan pendistribusian barang

11) Responden merupakan orang yang dimintai pendapat untuk membantu dalam kegiatan penelitian

12) Usahatani berkelanjutan merupakan kegiatan dalam penanganan usahatani jamur tiram dalam menghadapi kendala, dan mengembangkan agroindustri yang dapat memberikan keuntungan secara berkelanjutan.

\section{PEMBAHASAN}

Penerapan Fungsi Manajemen Usahatani Komoditas Jamur Tiram di UKM Agronusa Mushroom

Manajemen usahatani merupakan penerapan fungsi-fungsi manajemen dalam kegiatan usahatani. Menurut Maulidah (2012), fungsi-fungsi manajemen atau 
unsur-unsur manajemen dapat digunakan berdasarkan kondisi obyek yang akan diterapkan. Fungsi-fungsi manajemen yang dapat diterapkan pada perusahaan agribisnis adalah perencanaan, pengorganisasian, pelaksanaan, evaluasi, dan pengendalian. UKM Agronusa Mushroom adalah sebuah unit usaha yang fokus dalam budidaya jamur tiram, UKM Agronusa Mushroom menjalin kerja sama dengan CV. Arjuna Flora dalam kegiatan pemasaran jamur tiramnya dalam bentuk produk jadi. Berikut merupakan uraian fungsi-fungsi manajemen pada UKM Agronusa Mushroom:

\section{Perencanaan}

Perencanaan dalam kegiatan usahatani perlu dilakukan demi terwujudnya hasil produksi yang maksimal. Perencanaan usahatani dapat dikelompokkan menjadi perencanaan produksi, perencanaan teknologi, perencanaan sumberdaya manusia, perencanaan kemitraan, dan perencanaan pemasaran. Perencanaan dalam UKM Agronusa Mushroom diperlukan untuk menghasilkan jamur tiram yang bermutu. Berikut merupakan uraian tentang macammacam perencanaan dalam kegiatan usahatani di UKM Agronusa Mushroom.

1. Perencanaan produksi
Perencanaan produksi meliputi perencanaan bahan baku, penjadwalan produksi, perencanaan tata letak produksi, dan perencanaan biaya. Perencanaan bahan baku dibutuhkan untuk memilih bibit jamur tiram berkualitas, upaya mendapatkan bibit jamur yang berkualitas yaitu dengan memproduksi sendiri bibit jamur oleh pekerja disana dengan berbagai teknik penanganan yang optimal. Perencanaan jadwal produksi dilakukan agar jadwal tertata, sehingga dalam proses produksi tidak saling tumpang tindih antara kegiatan satu dengan lainnya. Perencanaan jadwal produksi juga dilakukan dengan tujuan agar menghasilkan produksi yang maksimal setiap harinya. Setiap hari UKM Agronusa Mushroom dapat memproduksi jamur tiram mentah dan siap dijual ke pasar dan didistribusikan ke CV. Arjuna Flora. Perencanaan biaya terdiri dari perencanaan biaya tetap dan biaya variabel. Menurut Astuti et al. (2018), biaya tetap merupakan biaya yang besar kecilnya tidak akan mempengaruhi jumlah yang dikeluarkan pada produk, sedangkan biaya variabel merupakan biaya yang besar kecilnya berpengaruh langsung pada produk. Perencanaan produksi meliputi layout tempat

produksi. Tata letak dalam pembuatan proses produksi juga harus diperhatikan 
supaya pengerjaan produksi lebih mudah.

Berikut merupakan gambaran layout

proses produksi jamur tiram di UKM

Agronusa Mushroom.

Gambar 1.1 Layout produksi jamur tiram di UKM Agronusa Mushroom

\begin{tabular}{|l|l|l|l|}
\hline Mesin Press & & Pembenihan & \multirow{2}{*}{ Rak Budidaya Jamur } \\
& \multicolumn{1}{|l|}{ Pembuatan Baglog } & \multirow{2}{*}{ Penyimpanan Bahan Baku } \\
\cline { 3 - 3 } & & $\begin{array}{r}\text { Pemindahan Benih } \\
\text { ke Baglog }\end{array}$ & \\
\hline Oven Sterilisasi & &
\end{tabular}

Gambar 1.1 Layout Produksi Jamur

Berdasarkan gambar 1.1, layout produksi jamur menggambarkan proses produksi jamur berada pada satu tempat produksi yang sama. Penyimpanan bahan baku berada di depan tempat produksi guna menaruh bahan baku pembuatan baglog. Bahan baku diletakkan di depan tempat produksi agar saat bahan baku datang tidak jauh memindahkan bahan baku ke tempat produksi. Proses produksi dilakukan di bagian belakang tempat produksi. Produksi dilakukan dengan pembenihan bibit ditempat yang steril. Pembuatan baglog dilakukan dengan mencampur bahan baku berupa serbuk gergaji, kapur, air, tepung jagung, dan serbuk kalsium, setelah baglog terbuat maka dilakukan proses pemadatan dengan menggunakan mesin press agar baglog padat dan mengurangi peluang tumbuh hama ulat dan jamur di dalam baglog. Baglog yang telah jadi akan memasuki proses sterilisasi. Sterilasasi pada baglog akan menjadikan baglog steril dari organisme lain yang dapat mengganggu budidaya. Setelah dilakukan sterilisasi benih jamur dipindah kedalam baglog. Setelah baglog dipindah maka dilakukan budidaya dengan meletakkan baglog pada rak budidaya.

2. Perencanaan teknologi

Perencanaan teknologi merupakan kegiatan perencanaan tentang teknologi pertanian meliputi alat-alat yang digunakan dalam proses produksi. Perencanaan 
teknologi dilakukan dengan tujuan mempermudah dalam pembuatan produk jamur tiram. Perencanaan teknologi perlu diperhatikan supaya hasil yang didapat lebih banyak dengan waktu yang terbatas. Teknologi yang digunakan pekerja di UKM Agronusa Mushroom adalah mesin pembuat baglog jamur berupa alat press yang berguna untuk membentuk produk agar siap dikemas., juga terdapat mesin oven untuk mensterilkan baglog dari organisme lain. Oven memiliki tekanan tertentu untuk mensterilkan baglog yang ada.

\section{Perencanaan sumber daya manusia}

Perencanaan sumber daya manusia meliputi perencanaan tenaga kerja yang ada di UKM Agronusa Mushroom. Perencanaan sumber daya manusia tidak akan lepas dari fungsi-fungsi manajemen sumber daya manusia (MSDM) yaitu staffing, pengembangan sumber daya manusia, kompensasi, keselamatan dan kesehatan, dan hubungan antar karyawan. Tenaga kerja dalam UKM Agronusa Mushroom sebanyak 35 orang dan terbagi menjadi beberapa tugas tiap orangnya. Tenaga kerja yang bekerja berasal dari masyarakat sekitar yang menetap di daerah sekitar usahatani jamur tiram. Pengembangan sumber daya manusia dilaksanakan dengan selalu mengarahkan para pekerja supaya melakukan tugasnya dengan lebih baik dan rutin setiap hari. Keselamatan dan kesehatan kerja karyawan atau pekerja juga perlu diperhatikan karena produksi yang maksimal juga dipengaruhi oleh banyaknya pekerja. Hubungan antar karyawan adalah hubungan tetangga atau masyarakat sekitar yang menetap di daerah sekitar usahatani jamur tiram.

4. Perencanaan kemitraan atau kelembagaan

Perencanaan kemitraan atau kelembagaan perlu juga diperhatikan karena dengan kerja sama mitra suatu usaha akan lebih berkembang dan memiliki koneksi yang luas. Perencanaan kemitraan tidak hanya bertujuan untuk mencari koneksi tetapi juga sebagai pemasok input produksi. Pemasok input produksi bekerja sama dengan pembudidaya jamur tiram yang lain. Perencanaan kemitraan di UKM Agronusa Mushroom biasanya dalam hal memenuhi bahan baku. Mitra yang bekerja sama dengan UKM Agronusa Mushroom untuk memenuhi bahan baku adalah kelompok tani disekitar lokasi budidaya.

5. Perencanaan pemasaran

Perencanaan pemasaran biasanya berupa pandangan tentang kondisi pasar dan akan dipasarkan kemana produk tersebut. Perencanaan pemasaran dilakukan dengan memerhatikan kondisi pasar saat 
ini, apakah konsumen di daerah ini tertarik dengan produk yang dihasilkan. Perencanaan pemasaran di UKM Agronusa Mushroom berorientasi pada bagaimana cara memasarkan jamur dalam bentuk tidak dikemas (curah) atau menjadi bahan dasar olahan. Pemasaran jamur tiram langsung dijual ke pasar dan terdapat beberapa yang ditawarkan untuk menjadi bahan dasar olahan jamur ke CV. Arjuna Flora. Jamur tiram yang akan dijual dipasaran memilih lokasi yang strategis yaitu dekat dengan tempat produksi, sedangkan pedagang yang akan memilih jamur sebagai bahan dasar olahan produk mereka akan datang ke tempat produksi jamur tiram. Pedagang yang akan mengolah jamur tiram menjadi bahan baku olahan lain berasal dari pihak UKM Agronusa Mushroom itu sendiri.

\section{Pengorganisasian}

Pengorganisasian merupakan sebuah aktivitas penataan sumber daya manusia yang tepat dan bermanfaat bagi manajemen, dan menghasilkan penataan dari karyawan. Pengorganisasian sangat diperlukan dalam melakukan usaha, karena pengorganisasian ialah kegiatan membagi atau menentukan tugas-tugas dari setiap stakeholders sehingga dapat tertata dengan sistematis dan terstruktur. Fungsi dari pengorganisasian adalah untuk mengatur tugas, wewenang, dan tanggung jawab setiap stakeholders. Pengorganisasian usahatani jamur tiram yang dilakukan di Agronusa Mushroom meliputi pengorganisasian produksi, teknologi, sumber daya manusia, kelembagaan, dan pemasaran.

\section{Pengorganisasian produksi}

Pengorganisasian produksi pada kegiatan usahatani jamur tiram merupakan suatu kegiatan pengaturan proses budidaya dari pembibitan sampai pemanenan. Kegiatan pengorganisasian dalam produksi ini meliputi pembagian tugas tenaga kerja, dari tujuh tenaga kerja semuanya tidak terfokus pada satu kegiatan. Mereka dibagi dalam beberapa tugas, ada dipembibitan dan pencampuran dan beberapa lagi ada di mesin press dan pemasangan tutup. Setalah kegiatan itu selesai hasil baglog tersebut ditata dan masuk pada proses inokulasi dan menunggu hingga putih semua, baru dilakukan pemindahan ke tempat yang siap panen. Tujuan dalam pembagian tenaga kerja dalam proses budidaya jamur tiram untuk mempercepat dan mempermudah kegiatan budidaya jamur tiram serta dikontrol dengan sebaik mungkin supaya dapat berjalan dengan efisien.

2. Pengorganisasian teknologi

Pengorganisasian teknologi adalah suatu kegiatan pembagian input-input 
teknologi yang digunakan dalam proses budidaya jamur tiram. Penggunaan teknologi pada suatu usaha yang dimaksudkan untuk mempermudah dan mempercepat pekerjaan suatu proses produksi. Teknologi yang digunakan dalam budidaya jamur ada 3 pengorganisasian teknologi yaitu pembibitan, proses baglog, pemanenan. Teknologi dalam pembibitan yaitu enkas untuk penyimpanan bibit dan autoclave untuk mensterilkan botol untuk pembibitan. Teknologi proses baglog yaitu teknologi tempat sterilisasi berguna mensterilkan baglog dan alat pres untuk menekan isi baglog. Teknologi pemanenan ini ada dua yaitu tempat pemanenan bambu dan tempat pemanenan tali yang ada di usahatani jamur tiram.

\section{Pengorganisasian Sumber Daya} Manusia

Pengorganisasian SDM merupakan suatu kegiatan melatih kemampuan tenaga kerja dan melakukan pembagian kerja sesuai bidangnya. Pengorganisasian ini bertujuan untuk melatih tenaga kerja agar bisa bekerja dengan baik. Pembagian dilakukan dengan membagi tugas kepada tenaga kerja pada proses pembibitan, pencampuran, masukkan ke dalam baglog, sterilisasi, pembibitan ke baglog inokulasi, dan pemanenan. Proses pembibitan dilakukan oleh tenaga kerja yang dibagi menjadi beberapa orang dikultur jaringan dan beberapa orang membuat F1 dan F2 kemudian masukkannya ke enkas, pada proses pembuatan baglog ada yang bertugas melakukan pencampuran seluruh bahan baku dan ada yang memasukkannya kedalam plastik, setelah itu dilakukan sterilisasi untuk menghindari tumbuhnya organisme lain yang dapat mengganggu kegiatan budidaya, setelah dilakukan proses sterilisasi beberapa tenaga kerja dibagi tugas untuk memasukkan bibit ke baglog yang sudah disterilisasi, selanjutnya baglog diinokulasi dan dipindah saat akan dapat dipanen.

4. Pengorganisasian kelembagaan

Pengorganisasian kelembagaan UKM Agronusa Mushroom jamur tiram yang ada di daerah tersebut melakukan bekerjasama dengan CV Arjuna Flora. Pemilik bekerjasama dan bergabung dengan kelompok tani yang ada di Desa Tulungrejo dengan tujuan untuk mempermudah dalam melakukan kegiatan proses budidaya jamur tiram. Kerjasama ini dapat membantu petani dalam penyediaan input-input produksi dan juga untuk mensosialisasikan tentang inovasi-inovasi terbaru dalam proses budidaya dan juga sharing terkait permasalahan yang dihadapi dalam usahatani jamur tiram.

5. Pengorganisasian pemasaran 
Pengorganisasian pemasaran merupakan penempatan atau pembagian proses pemasaran untuk menjualkan hasil panen yang sudah didapatkan. Pengorganisasian pemasaran bertujuan agar dalam melakukan pemasaran dapat berjalan efektif. Pengorganisasian yang terjadi di daerah tersebut adalah pengorganisasian keluarga dan bermitra dengan CV. Arjuna Flora. Pemasaran yang dilakukan adalah dengan mengolah dulu hasil panen yang sudah dipanen sehingga menghasilkan beberapa produk sebelum dipasarkan oleh pihak UKM Agronusa Mushroom sendiri dengan menjualan langsung hasil panen kepada konsumen yang merupakan warga sekitar maupun menjual melalui pedagang di pasar atau dititipkan di CV. Arjuna Flora.

\section{Pelaksanaan}

Pelaksanaan merupakan tahap dimana seluruh kegiatan yang telah direncanakan dan dikoordinasikan akan dilaksanakan. Seluruh aspek yang telah dipersiapkan dalam tahap perencanaan akan direalisasikan dalam tahap pelaksanaan. Kegiatan pelaksanaan produksi dilakukan oleh UKM Agronusa Mushroom dalam usahatani jamur tiram ini yaitu kegiatan budidayanya. Terdapat beberapa tahap dalam pelaksanaan kegiatan budidaya jamur tiram di Agronusa Mashrom.

\section{Pelaksanaan produksi}

Tahap pertama yaitu dengan menyiapkan tempat atau ruangan yang akan digunakan untuk dilakukannya setiap kegiatan atau proses budidaya jamur tiram tersebut. Ruangan yang digunakan harus dipersiapkan terlebih dahulu, disterilkan dari hama dan penyakit tanaman serta jamur lain yang nantinya akan mengurangi produktivitas jamur tiram yang dibudidayakan. Ruangan juga sebaiknya dapat menjaga suhu dan kelembaban. Ruangan yang digunakan menggunakan dinding dari anyaman banbu beratapkan genteng dan beralaskan tanah, hal ini dimaksudkan agar kelembaban tetap terjaga. Ruangan tersebut berisi rak-rak yang ditata sedemikian rupa, berjajar antara satu sama lain dan diberi sekat kosong ditengah untuk perawatan. Rak-rak tersebut digunakan untuk tempat menata baglog.

2. Pelaksanaan teknologi pelaksanaan teknologi dilakukan dalam kegiatan persiapan bibit dimulai dengan memilih bibit yang baik, kemudian menanam bibit-bibit tersebut di dalam media tanam berupa baglog. Baglog yang digunakan dibuat sendiri oleh para pekerja dengan menggunakan beberapa bahan, yaitu serbuk gergaji, kapur, air, tepung jagung, bekatul dan kalsium. Pembuatan baglog ini dimulai dengan menyampurkan 
seluruh bahan, kemudian memasukkannya ke dalam kantong plastik, setelah itu dilakukan pengepresan dengan menggunakan sebuah alat press khusus, yang berguna untuk memadatkan baglog. Baglog yang sudah dipadatkan kemudian disterilkan kembali dengan menggunakan alat uap atau steamer untuk menghilangkan sisa-sisa mikroba yang mungkin tumbuh dan dapat mengganggu produktivitas jamur tiram nantinya. Baglog yang telah steril kemudian siap untuk diisi dengan bibit jamur yang telah disiapkan. Baglog-baglog tersebut kemudian disusun di atas rak-rak yang telah disiapkan. Baglog diletakkan secara horizontal dengan lubang baglog menghadap ke arah samping. Peletakan baglog secara horizontal dimaksudkan agar kapasitas air yang masuk ke dalam baglog tidak terlalu banyak karena dapat mengganggu pertumbuhan jamur tiram yang dibudidayakan. Penyiraman dilakukan cukup dengan melakukan penyiraman pada tanah (lantai) untuk tetap menjaga kelembaban ruangan tersebut, penyiraman juga bias dilakukan dengan sprayer. Kegiatan penyiraman pada budidaya jamur tiram diusahakan agar tidak terlalu banyak mengeluarkan air. Hal ini karena jamur eksternal dapat dengan mudah tumbuh. Baglog yang sudah tertutup sempurna oleh miselium menandakan jamur akan segera panen. Selang 1-2 minggu sejak pembukaan tutup baglog menandakan bahwa jamur akan tumbuh lalu kemudian bisa dipanen. Baglog yang sudah selesai dipakai bisa dibuang atau digunakan sebagai pupuk kompos. Jamur yang telah dipanen kemudian dikemas menggunakan plastik untuk menjaga kadar air dan kualitas jamur yang dihasilkan.

3. Pelaksanaan Sumber daya manusia

Pelaksanaan sumber daya manusia yang bekerja di UKM Agronusa Mushroom di bagian budidaya memiliki tugas sebagai tenaga kerja. Tenaga kerja tersebut sebelum benar-benar melakukan tugasnya, diberikan pelatihan yang berkaitan dengan tata cara budidaya jamur tiram yang baik serta tugastugas lain yang meliputi penggunaan teknologi yang ada. Tenaga kerja yang bekerja di bawah UKM Agronusa Mushroom mendapatkan jobdesc yang dilakukan secara bersama-sama untuk menyiapan media tanam, pressing, perawatan jamur dalam masa inokulasi, dan pemanenan jamur tiram yang tepat pada waktunya secara bergantian.

4. Pelaksanaan kelembagaan

Pelaksanaan kelembagaan yang dilakukan oleh UKM Agronusa Mushroom dalam menjalankan usahanya, berkaitan dengan kemitraan yang dilakukan dalam pemasaran jamur tiram yang belum diolah. 
Kemitraan yang dilakukan oleh UKM Agronusa Mushroom dalam pemasarannya melakukan kerjasama dengan pedagang di pasar. UKM Agronusa Mushroom juga melakukan kemitraan dengan lembaga pemasaran lainnya pada kegiatan agroindustri jamur tiram. UKM Agronusa Mushroom bekerja sama dengan CV Arjuna Flora biasa melakukan pertemuan dengan petani jamur tiram lainnya di kegiatan rutin yang diadakan oleh golongan kelompok tani.

\section{Pelaksanaan pemasaran}

Pelaksanaan pemasaran budidaya jamur tiram di UKM Agronusa Mushroom dilakukan dengan melakukan system supply dengan pedagang di pasar. Pedangan di pasar biasa mengambil jamur tiram dari Agronusa Mushroom kemudian dipasarkan sendiri. Pemasaran hasil olahan jamur oleh Agronusa Mushroom dilakukan di berbagai tempat seperti di kampus, dan pemasaran secara online di media sosial. UKM Agronusa Mushroom juga dibantu oleh CV. Arjuna Flora sebagai mitra dalam memasarkan produk olahannya sampai ke luar kota, seperti Surabaya sampai Jakarta, dan juga di seluruh Indonesia.

Kendala yang sering terjadi dalam proses budidaya jamur tiram ini adalah munculnya ulat dan jamur lain yang dapat merugikan bagi jamur tiram itu sendiri sehingga menyebabkan produktivitas jamur berkurang. Ulat muncul akibat ruangan yang terlalu lembab mengakibatkan kelembaban pada media tanam atau baglog juga bertambah, sehingga kelembaban ruangan harus tetap terjaga agar ulat tidak tumbuh berkembang, selain itu pertumbuhan ulat juga dapat dicegah dengan memberikan sirkulasi pada media tanam. Ulat biasa menyerang jamur yang berusia 80 hari.

\section{Evaluasi dan Pengendalian}

Evaluasi dan pengendalian merupakan kegiatan yang dilakukan sebagai tahap akhir dari kegiatan manajemen suatu produksi. Evaluasi merupakan suatu kegiatan penilaian akan segala hal yang dilakukan selama kegiatan produksi. Evaluasi dilakukan untuk mengetahui kendala-kendala yang terjadi selama proses produksi. Evaluasi dilakukan secara terus-menerus dan berkala mulai dari tahap perencanaan hingga akhir kegiatan produksi berakhir, sehingga apabila terdapat penyimpangan selama kegiatan usaha berlangsung yang dapat merugikan dapat segera dilakukan tahap pengendalian. Pengendalian merupakan suatu kegiatan yang dilakukan untuk mengatasi segala kendala dan penyimpangan selama kegiatan produksi berlangsung. Pengendalian 
dilakukan untuk menjamin agar setiapkegiatan mulai dari awal hingga akhir dapat berjalan sesuai dengan rencana. Evaluasi dan pengendalian dilakuakan pada beberapa aspek, antara lain:

\section{Evaluasi dan Pengendalian Produksi}

Evaluasi yang dilakukan selama proses budidaya jamur tiram di UKM Agronusa Mushroom meliputi penyediaan bahan baku seperti bibit dan baglog. Kegiatan penyediaan bibit harus diperhatikan karena bibit merupakan hal yang penting dalam kegiatan produksi. Proses pembuatan baglog juga harus diperhatikan terutama dalam penyediaan bahan baku pembuatan baglog itu sendiri, seperti penyediaan serbuk gergaji, kapur, air, tepung jagung, dan serbuk kalsium. Bahan-bahan tersebut harus dapat terpenuhi agar seluruh pelaksanaan budidaya dapat berjalan sesuai rencana. Tahap evaluasi dilakukan untuk menentukan kegiatan pengendalian yang tepat untuk mengatasi penyimpangan selama kegiatan budidaya. Pengendalian yang dilakukan selama proses budiadaya jamur tiram dilakukan untuk menjaga alur produksi tetap sesuai dengan rencana.

\section{Evaluasi dan Pengendalian Teknologi}

Teknologi yang terdapat dalam usaha jamur tiram di UKM Agronusa Mushroom adalah mesin press dan mesin uap yang digunakan untuk mensterilkan baglog sebagai media tanam. Evaluasi teknologi yang dilakukan yaitu dengan memeriksa mesin-mesin tersebut secara rutin, sehinggga apabila terjadi kerusakan yang dapat menghambat kegiatan produksi dapat segera ditemukan solusinya. Mesin tersebut dekandalikan oleh tenaga kerja agar dapat mempermudah kegiatan produksi terutama dalam pembuatan baglog. Mesin tersebut tidak boleh digunakan dengan asal-asalan, harus sesuai dengan standar operasional yang telah dianjurkan sehingga mengurangi risiko yang mungkin muncul dan dapat mengurangi kualitas produksi yang dihasilkan.

3. Evaluasi dan Pengendalian Sumberdaya Manusia

$$
\text { Evaluasi sumberdaya manusia }
$$
dilakukan seorang manajer dengan melakukan pengawasan dan penilaian terhadap kinerja setiap karyawan yang bekerja di Agronusa Mushroom. Pengawasan dan penilaian ini dilakukan untuk mengontrol seluruh kinerja tenaga kerja apakah sudah sesuai dengan tugas masing-masing pekerjaanya. Hasil evaluasi yang dilakukan akan menentukan seberapa besar produktivitas pekerja dalam kegiatan produksi sehingga apabila terdapat pekerja yang mengalami penyelewengan tugas atau 
tidak melakukan tugasnya sesuai dengan perintah maka akan dilakukan pengendalian berupa teguran secara langsung kepada pekerja tersebut.

4. Evaluasi dan pengendalian

Kelembagaan

UKM Agronusa Mushrom memiliki mitra usaha yaitu CV Arjuna Flora dan kelompok tani di Desa Tulungrejo. UKM Agronusa Mushroom juga bekerja sama dengan pedagang-pedagang pasar serta pengusaha-pengusaha jamur tiram lainnya. UKM Agronusa Mushroom rutin melakukan pertemuan dengan pengusahapengusaha jamur tiram lain untuk sharing masalah-masalah yang terjadi selama kegiatan produksi berlangsung. Pertemuan ini dilakukan tidak hanya untuk berbagi solusi masalah yang dihadapi, tetapi juga berbagi informasi-informasi penting terkait seluruh aspek dalam budidaya jamur tiram yang dilakukan. Informasi-informasi tersebut dapat berupa informasi pasar dan lainnya.

\section{Evaluasi dan Pengendalian Pemasaran}

Kegiatan pemasaran yang dilakukan di Agronusa Mushroom meliputi penjualan produk hasil budidaya jamur tiram secara langsung. Evaluasi dalam pemasaran dilakukan untuk mengontrol seluruh kegiatan pendistribusian dari mulai pengemasan produk hingga produk tersebut sampai di tangan konsumen. Kegiatan ini dilakukan untuk mengetahui apakah kegiatan pemasaran berjalan dengan baik, serta kualitas dan kuantitas produk yang dijual sesuai dengan target pasar yang telah ditentukan.

\section{Manajemen Usahatani Komoditas Jamur Tiram Bekerlanjutan di UKM} Agronusa Mushroom

Penerapan model usaha yang dilakukan oleh UKM Agronusa Mushroom dalam menjalankan usahatani jamur tiram cukup sederhana. Tidak ada kegiatan manajemen usaha yang terlalu kompleks dalam kegiatannya. Konsep manajemen dalam usahatani sudah terlaksana dengan cukup baik mulai dari kegiatan penyediaan input produksi, budidaya jamur, sampai dengan pemasaran jamur tiram yang masih berupa produk mentah. Konsep manajemen usahatani yang berjalan pada usahatani jamur tiram di UKM Agronusa Mushroom mendukung untuk mendapatkan keuntungan secara maksimum dalam kegiatan produksinya melalui manajemen usahhatani berkelanjutan.

Manajemen usahatani berkelanjutan yang diterapkan dalam usahatani jamur tiram memberikan keuntungan berdasarkan faktor-faktor yang mendukung di dalamnya. Menurut (Kusrini et al (2019), 
ada beberapa faktor yang menjadi prioritas dalam kegiatan usahatani jamur tiram, yaitu keadaan ekologi, aspek keuangan, budaya masyarakat, kelembagaan, tenaga kerja, dan teknologi di dalamnya. Faktor-faktor tersebut menjadi penentu apakah manajemen usahatani jamur tiram berskala menengah di UKM Agronusa Mushroom dapat berjalan dengan baik atau tidak. Semua faktor pendukung dalam kegiatan usahatani jamur tiram di UKM Agronusa Mushroom dikendalikan oleh manajer dalam usahatani tersebut.

Keadaan ekologi berpengaruh pada kegiatan budidaya jamur tiram karena berkaitan dengan keadaan iklim, serangan hama, dan ketersediaan air. Keadaan iklim yang optimal bagi budidaya jamur tiram adalah daerah yang memiliki iklim tropis dan UKM Agronusa Mushroom telah melakukan keputusan yang benar untuk membudidayakan jamur tiram di Desa Tulungrejo Kecamatan Bumiaji Kota Batu. Keadaan iklim mikro yang dibuat oleh UKM Agronusa Mushroom untuk memberikan kelembaban dan airase pada baglog jamur tiram telah sesuai. Hal ini dibuktikan dengan produktivitas jamur tiram yang berhasil dibudidaya oleh UKM Agronusa Mushroom.

Pengendalian hama di sekitar lokasi budidaya jamur tiram sangat perlu diterapkan. Jamur tiram sangat mudah terkontaminasi oleh bakteri jahat dan jamur penganggu dari luar saat dalam proses inokulasi. Jamur tiram yang terkena penyakit, akan menjadi kerdil dan menghasilkan tudung yang mengkerut. Penggunaan pestisida sangat tidak dianjurkan dalam budidaya jamur tiram, karena jamur tiram adalah tanaman organik dalam budidayanya dan mudah terkontaminasi dengan bahan-bahan kimia, sehingga penyemprotan pestisida yang digunakan untuk mempertahankan kesehatan jamur hanya berupa antiseptik, sterilisasi tempat sebelum baglog dibiarkan untuk berinokulasi, dan pemberian air yang cukup untuk mencegah tumbuhnya jamur pengganggu.

$$
\text { Aspek keuangan sangat }
$$
berpengaruh dalam keberlanjutan sebuah usaha, terlebih usaha komoditas jamur tiram. UKM Agronusa Mushroom memiliki modal yang cukup besar untuk mendapatkan layout usaha yang diinginkan. Investasi dalam bentuk modal tetap berupa bangunan sangat diperlukan, meski kegiatan budidaya sebenarnya bisa dilakukan di mana saja. Alokasi biaya yang diterapkan oleh UKM Agronusa Mushroom dalam usahatani jamur tiram cukup baik. Indikatornya dapat dilihat dari keuntungan yang didapatkan oleh produsen, yang dapat 
menutupi modal usaha yang dikeluarkan. Strategi yang dilakukan oleh UKM Agronusa Mushroom cukup baik, karena jamur tiram yang dibudidaya tidak hanya dipasarkan dalam bentuk mentah, tetapi juga mulai dipasarkan dalam bentuk olahan yang dapat meningkatkan nilai tambah produk itu sendiri.

Budaya masyarakat yang berkembang di Desa Tulungrejo Kecamatan Bumiaji Kota Batu telah sepenuhnya mendukung kegiatan usahatani jamur tiram. Usahatani jamur tiram yang dilakukan oleh UKM Agronusa Mushroom memanfaatkan tenaga kerja dari masyarakat sekitar untuk kegiatan agroindustri jamur dan budidaya jamur. Tenaga kerja yang dibutuhkan dalam kegiatan budidaya berjumlah tiga orang, yang bekerja secara bersama-sama dalam kegiatan membungkus serbuk kayu, pembuatan baglog, dan perawatan baglog. Tidak ada pembagian kerja secara khusus karena budidaya jamur tiram cukup fleksibel dan mudah dilakukan. Pembuatan baglog dalam kegiatan budidaya telah dibantu dengan teknologi mesin press yang bekerja cukup cepat. Mesin press yang digunakan dapat membantu menghasilkan lebih dari 400 baglog dalam sehari untuk dijadikan sebagai media tanam. Mesin press dapat memudahkan kinerja tenaga kerja dalam pembuatan baglog jamur tiram.

UKM Agronusa Mushroom telah menjalin kerja sama dengan penjual di pasar dan menjadi supplier dalam sebuah kegiatan pemasaran. UKM Agronusa Mushroom juga telah bermitra dengan gabungan kelompok tani yang berda desa Tulungrejo dan desa tetangga. Biasanya, dilakukan pertemuan antar anggota untuk saling belajar satu sama lain mengenai usahatani yang telah dilakukan oleh para petani. Kegiatan pertemuan ini biasanya dibarengi dengan kegiatan arisan dan metode-metode belajar yang menarik, agar petani tidak bosan dalam menjalankan sebuah usahatani.

Kendala yang dialami UKM Agronusa Mushroom pada budidaya jamur tiram adalah terjangkitnya jamur tiram oleh patogen. Kendala ini telah diberikan solusi dengan lebih memperhatikan dan mensterilkan iklim mikro yang ada di sekitar baglog. Jamur eksternal cepat berkembang dalam keadaan iklim yang terlalu lembab, sehingga solusi yang tepat adalah dengan memperhatikan kelembaban di sekitar ruangan inokulasi dan lebih memperketat sirkulasi keluar-masuknya orang di dalam rumah budidaya.

Penerapan konsep manajemen usahatani berkelanjtan yang dilakukan oleh 
UKM Agronusa Mushroom telah baik, tetapi ada beberapa aspek yang dapat berpotensi menjadi risiko bila hanya dipertahankan begitu saja. Pemeliharaan jamur tiram harus dilakukan dengan lebih fokus pada pengendalian hama dan penyakit. Jamur tiram sangat mudah terkontaminasi oleh bakteri. Baglog harus segera dipisahkan dari baglog lainnya sehingga jamur tiram yang tumbuh tidak dapat dipanen. Maka, disarankan untuk lebih perhatian terhadap iklim mikro di sekitar baglog.

\section{KESIMPULAN}

Kegiatan manajemen usahatani komoditas jamur tiram di UKM Agronusa Mushroom telah menerapkan masingmasing fungsi manajemen mulai dari perencanaan, pengorganisasian, pelaksanaan, evaluasi dan pengendalian dengan baik.

Penerapan konsep manajemen usahatani berkelanjutan yang dilakukan oleh UKM Agronusa Mushroom sudah dilakukan dengan baik. Konsep manajemen berkelanjutan yang diterapkan meliputi keadaan ekologi, pemeliharaan hama dan penyait tanaman jamur tiram, aspek keuangan, budaya masyarakat, kelembagaan, tenaga kerja, dan teknologi di dalamnya.

\section{SARAN}

1. Bagi pemerintah, sebaiknya juga memperhatikan produksi komoditas jamur tiram agar komoditas ini juga dapat menjadi komoditas unggulan, serta menambahkan peran kemitraan pada komoditas jamur tiram sehingga memudahkan pelaku usaha dalam mendidtribusikan produk yang dihasilkan.

2. Bagi petani, terutama di UKM Agronusa Mushroom sebaiknya lebih memperluas kemitraan agar proses penyaluran produk dapat lebih luas, penataan baglog juga seharusnya bisa lebih rapi dan tidak dibiarkan terbengkalai di area penanaman jamur tiram serta perlu dilakukan perawatan yang optimal pada alat dan mesin teknologi agar mengurangi resiko kerusakan, sehingga usaha yang dijalankan tetap pada konsep manajemen usahatani berkelanjutan.

3. Bagi mahasiswa, diharapkan bisa lebih mendalami pengetahuan tentang komoditas jamur tiram agar suatu saat nanti juga dapat ikut andil dalam kemajuan produksi usaha komoditas jamur tiram dimasa depan, dengan teknologi yang modern dan penanganan yang tepat. 


\section{DAFTAR PUSTAKA}

Astuti, R. W. A. Zakaria., T. Endaryanto. 2018. Analisis Biaya dan Pendapatan Usaha Pedagang Sayuran di Pasar Tamin Kota Bandar Lampung. JIIA. 6(3): 249256.

BPS Kota Batu. 2020. Produksi dan Luas Lahan Jamur Tiram di Kota Batu Tahun 2016-2018. diakses pada tanggal 2 Mei 2021, pukul 11.42 WIB.

https://batukota.bps.go.id/subject/5 5/hortikultura.html\#subjekViewTab 3

Firdaus, M. 2017. Manajemen Agribisnis. Jakarta: Bumi Aksara.

Israwati, I., S. Saediman., dan N. Rahmah. 2018. Peran Perempuan dan Strategi Keberlanjutan Nafkah Rumahtangga Petani Hortikultura Kabupaten Konawe. Jurnal Sosio Agribisnis 3(1): 7-15.

Kusrini, N., R. Sulistiawati, dan Imelda. 2019. Priority Factors in The Development of Sustainable Oyster Mushroom Agribusiness. Jurnal Manajemen dan Agribisnis. 16(1): 86-96.

Lailatusysyukriah. (2015). Indonesia dan
Konsepsi Negara Agraris. Jurnal Seuneubok Lada. 2(1): 1-8.

Maulidah, S. 2012. Pengantar Manajemen Agribisnis. Malang: UB Press

Retnaningsih, N., dan N. C. Bambang. 2018. Strategi Pengembangan Jamur Tiram (Pleurotus Ostreatus) di Kelompok Tani Aneka Jamur Desa Gondangmanis Kecamatan Karangpandan Kabupaten Karanganyar. SEPA: Jurnal Sosial Ekonomi Pertanian Dan Agribisnis. 14(1): 61-68.

Sjamsir, Z., 2017. Pengembangan Pertanian dalam Pusaran Kearifan Lokal. Makasar: CV. Sah Media.

Wulandari, E., Y. Deliana., dan S. Fatimah. 2017. Kerupuk Kulit Mangga sebagai Upaya Diversifikasi Produk Pangan. Jurnal Pengabdian Kepada Masyarakat. 1(1): 10-13.

Zulfarina, Z., E. Suryawati., Y. Yustina., R. A. Putra., dan H. Taufik. 2019. Budidaya Jamur Tiram dan Olahannya untuk Kemandirian Masyarakat Desa. Jurnal Pengabdian Kepada Masyarakat (Indonesian Journal of Community Engagement). 5(3): 358-370. 